\title{
Document Version Workflow Status
}

National Cancer Institute

\section{Source}

National Cancer Institute. Document Version Workflow Status. NCI Thesaurus. Code C93479.

The workflow status associated with a document version from submission thru abstraction. 